\title{
Carbon stable isotope analysis of cereal remains as a way to reconstruct water availability: preliminary results
}

Article

Accepted Version

Flohr, P., Muldner, G. and Jenkins, E. (2011) Carbon stable isotope analysis of cereal remains as a way to reconstruct water availability: preliminary results. Water History, 3 (2). pp. 121-144. ISSN 1877-7244 doi: https://doi.org/10.1007/s12685011-0036-5 Available at https://centaur.reading.ac.uk/35721/

It is advisable to refer to the publisher's version if you intend to cite from the work. See Guidance on citing.

Published version at: http://link.springer.com/article/10.1007/s12685-011-0036-5

To link to this article DOI: http://dx.doi.org/10.1007/s12685-011-0036-5

Publisher: Springer

All outputs in CentAUR are protected by Intellectual Property Rights law, including copyright law. Copyright and IPR is retained by the creators or other copyright holders. Terms and conditions for use of this material are defined in the End User Agreement.

$\underline{\text { www.reading.ac.uk/centaur }}$

\section{CentAUR}


Central Archive at the University of Reading

Reading's research outputs online 
Carbon stable isotope analysis of cereal remains as a way to reconstruct water availability: preliminary results

Pascal Flohr, Gundula Müldner, Emma Jenkins

\section{Introduction}

Regular access to water is essential for the existence of any human settlement. Besides drinking water, enough water to sustain vegetation or grow crops is vital and water shortage is the most pressing problem for many developing countries today. Understanding water availability and management in the past is also an important research theme in archaeology and it is often believed that water shortages led to the abandonment of some well-established and large scale settlements. For example, an arid event in the seventh millennium BC (around 8,200 years ago and therefore termed the ' $8.2 \mathrm{ka}$ event') is sometimes linked with the abandonment of early (Pre-Pottery Neolithic) farming settlements in the Southern Levant (Migowski et al. 2006; Staubwasser and Weiss 2006), while a possible short arid period which occurred sometime around the end of the fourth millennium $\mathrm{BC}$ has been connected with the end of the Uruk culture and the late Chalcolithic - Early Bronze Age transition (Roberts et al. 2011). In addition, a dry period which is detectable in several climate proxies around $2200 \mathrm{BC}$ (c. $4.2 \mathrm{ka} \mathrm{BP}$ and termed the $4.2 \mathrm{ka}$ event), and is thought to have lasted for about 300 years, has often been related to cultural collapse, for example the collapse of the Akkadian empire (Weiss et al. 1993; Migowski et al. 2006; deMenocal 2001; Staubwasser and Weiss 2006). It is however difficult to be certain about the synchronicity of climatic and socio-economic changes (Roberts et al. 2011), and it is even harder to attest causality between the two (Akkermans et al. 2010). When investigating past human responses to environmental change, archaeologists are therefore always seeking to find new ways to identify past water availability and irrigation. This paper presents some preliminary results from ongoing research which aims to test the validity of using plant isotope ratios to determine past water availability. To achieve this end, we carried out isotope analysis of modern crops that were experimentally grown at three different crop growing stations where the environmental variables were closely monitored. This allows us to determine if the same crop, grown 
under similar conditions in different locations reacts to changes in the level of irrigation in a uniform manner or if other environmental variables, which affect the isotopic composition of the crops, introduce too much additional variation for this method to be really useful for reconstructing water availability from plant remains retrieved from archaeological sites in the Near East.

Water management in the Near East

As $200 \mathrm{~mm}$ of annual rainfall is perceived as the absolute minimum requirement for dry-farming, and at least $300 \mathrm{~mm}$ is needed for stable harvests (Charles et al. 2003), many areas in the Near East are marginal areas for rain-fed cultivation. Furthermore, rainfall can fluctuate annually and even within a single year. Rainfall in the Near East tends to fall between November and April only and generally falls in heavy outbursts. In addition, often no perennial water sources are present and in the Southern Levant for example, many places rely on seasonal streams (wadis). To secure stable harvests or even to gain food surplus, irrigation systems can be used (Ertsen 2010). Canal irrigation systems have been linked to developing social complexity in certain areas of the world, such as Mesopotamia and Egypt (Scarborough 2003), although the exact nature of this is still very much debated (see for example Ertsen 2010; Price 1994; Hunt 1994; Butzer 1996; Davies 2009; Harrower 2009).

Much of the debate revolves around the earliest use of irrigation. Currently, sound evidence for extensive canal systems in Mesopotamia only exists from the third millennium onwards, whereas numerous indications of increasing social complexity already appear before, for example, with fourth millennium monumental buildings and depictions of a leader-like figure at the southern Mesopotamian site of Uruk (Matthews 2009; Davies 2009; Wenke 1990; Postgate 1994). It is possible that forms of artificial irrigation which are archaeologically less visible were in use at this earlier time already; however, archaeologists are currently lacking the methodological tools to detect these with sufficient certainty. Understanding the nature of the early settlements in arid regions of the Near East poses a similar problem: Although numerous examples of elaborate water management systems and written sources are present for later periods (Oleson 2001; Bienert and Häser 2004; Bellwald and alHuneidi 2003), much less evidence is available for earlier, prehistoric times, although it is probably 
then that the use of irrigation first evolved. Developing new methods to detect irrigation in the archaeological record is therefore of vital importance for understanding the beginnings of human water management.

In general, gathering evidence for early crop water management is difficult. As already discussed, direct archaeological evidence, in the form of structural evidence, is scarce in the Near East, especially for the earlier periods. This may be because water management systems were simply rare, although it is just as likely that traces of them have been destroyed by later over-lying constructions, agricultural activities such as ploughing, as well as geomorphological processes, for example the down-cutting of wadis and the deposition of colluvium (Philip 2008). In addition, structures are often hard to date, as they are frequently found off-site and thus outside well-stratified excavations and without associated finds. Even when they are excavated, no finds might be associated with the structures, as was found for a terrace wall in the Wadi Qattar area in Jordan (Bastert and Lamprichs 2004). Moreover, it is often hard to distinguish between structures used for capturing and storing drinking water and those used for irrigation of crops.

Nevertheless, structural evidence for some form of water management is present in the Near East from the Neolithic period onwards. Initially, these (probably) took the form of lined springs and wells (Oleson 2001). Wells, dug out in bedrock or soil, are found at Pre-Pottery Neolithic B Cyprus (Peltenburg et al. 2000), later Pre-Pottery Neolithic C 'Atlit Yam, off the coast of Israel (Galili and Nir 1993), and the Pottery Neolithic site Sha'ar Hagolan in the Jordan Valley (Garfinkel et al. 2006) ${ }^{1}$. While these earliest structures were probably mainly intended to secure drinking water supplies, terrace walls are more likely to be linked to cultivation practices, as they could have been used to avoid soil erosion and to capture water for field systems (Kuijt et al. 2007). The possibly earliest finds of terrace walls in the Southern Levant date to around 6000 BC (Pottery Neolithic) and were found at Dhra', near the Dead Sea, on the Southern Jordan Valley slopes (Kuijt et al. 2007), although it could

\footnotetext{
${ }^{1}$ The Cyprian wells date to around 8000 BC (Peltenburg et al. 2000). The PPNB period in the Near East can be dated to $11000-8900 \mathrm{BP}$, or roughly to around c. $8700-6800 \mathrm{cal} \mathrm{BC}$, and the PPNC to $8900-8300 \mathrm{BP}$, around the beginning of the seventh millennium BC. The Pottery Neolithic, or Late Neolithic period dates to $c .8300$ 6800 BP, and falls within the seventh and sixth millennia BC (dates after Akkermans and Schwartz 2003; Rollefson 2008).
} 
be suggested that these served solely as protection against flash floods, rather than crop water management. Barrages in wadis can be used to capture water, which can then be used either as drinking water or to irrigate crops. Barrages were found at Wadi Abu Tulayha and Wadi arRumwayshi ash-Sharqi in the Jafr Basin in Jordan (Fujii 2007, 2008). Two of these were interpreted as having been used for crop water supply, while others seem to have functioned to supply drinking water (Fujii 2007). The barrages were dated to the PPNB (Fujii 2007, 2008), but this date is not entirely certain (see discussion in Finlayson et al. 2011). At Wadi Abu Tulayha a possible cistern has been found as well (Fujii 2008), although the interpretation of this structure as such might not be completely secure (Finlayson et al. 2011).

No further evidence for Neolithic water management concerning cultivation of crops in the Southern Levant has, so far, been found. Evidence from further afield shows that artificial channels were present possibly as early as $6000 \mathrm{BC}$ at Choga Mami in Iraq and Tepe Pardis in Iran (Gillmore et al. 2009; Oates and Oates 1976 cited in Gillmore et al. 2009). The evidence for the channel at Tepe Pardis being man-made seems especially convincing, as does the dating of the structure (Gillmore et al. 2009). Nevertheless, as with many structural remains and despite the fact that it resembles modern irrigation channels (Gillmore et al. 2009), it is difficult to be sure that it was indeed used for crop irrigation. It is equally possible that it was used for some other purpose, for example to transport water to a reservoir.

More substantial structures for water management in the Southern Levant can be found from the Early Bronze $\mathrm{Age}^{2}$ onwards. At Jawa in northern Jordan, elaborate water systems dated to the late fourth millennium $\mathrm{BC}$ were found with dams catching runoff rainwater into channels, which led via sluice-gates to cisterns and pools (Betts 1991; Helms 1981; Helms 1989). However, whereas these systems were associated with fields, no direct evidence for the water being used for irrigation was present (Betts 1991). Moreover, it has been calculated that at least under current climate conditions, irrigating just 7 ha of fields would take up about $40 \%$ of the captured water (Whitehead et al. 2008).

\footnotetext{
${ }^{2}$ The Early Bronze Age in the Southern Levant is generally dated from the early fourth millennium (3400/3300BC) to $c$. 2000 BC (Philip 2008; Palumbo 2008).
} 
As wadis with possibilities for terraced farming are just $5 \mathrm{~km}$ away and dry-farming is possible at less than $10 \mathrm{~km}$ distance (Helms 1981), it is possible that the water system was used for drinking water only whereas the majority of crops were grown elsewhere.

Many other examples for water management appear in the Southern Levant from the Early Bronze Age onwards, such as cisterns and reservoirs at Early and Middle Bronze Age sites and many sites from the Iron Age (Oleson 2001; Mabry 1995; Philip 2008). ${ }^{3}$ A 1.5 ha large reservoir was found at Early Bronze Age Tell Handaquq (Mabry 1995, 1989). Possible Early Bronze Age dams are found for example in the Hawran area (Braemer et al. 2009), and also nearby Early Bronze Age Tell Handaquq in the Jordan valley two dams were found probably originally spanning the wadi there, and thought to be contemporary with the settlement (Mabry 1989, 1995). Again, it is not possible to be sure if part of the function of these structures would have been to supply crops with water.

Another line of evidence for water management can be formed by settlement patterns, often in combination with the presence of certain plant species in dry areas. However, this is not direct evidence, and except for possible climate differences from today, crops might have been brought in from further away. For the Southern Levant, it has been proposed that irrigation, probably in the form of floodwater irrigation, started in the Chalcolithic period (fifth to early fourth millennium BC). This has been argued on the basis of settlement patterns in combination with archaeological remains: because sites are present in now marginal zones, but archaeobotanical remains were found needing a substantial amount of water, it has been argued that if the climate was not wetter, some form of water management was used to grow the crops (Bourke 2008). Legumes, fruits and olives were found for example at Tulaylat Ghassul in the Jordan Valley (Meadows 2001, 2005 and Meadows in Bourke et al. 2000, cited in Bourke 2008). In the same way, it is thought that floodwater management was used in the northern Negev around the same time, in order to support the settlements found there (Levy 1995). A similar argument has been made for the Early Bronze Age in the Southern Levant, where the locations of settlements (Prag 2007; Mabry 1995) and the presence of certain crops such as flax, figs,

\footnotetext{
${ }^{3}$ The Middle Bronze Age can be dated from c. 2000-1600 BC and the Iron Age in the Southern Levant starts around $1050 \mathrm{BC}$.
} 
grapes, emmer and bread wheat at sites in relative dry areas, such as Bab edh-Dhra and Tell Handaquq in the Jordan Valley and Arad in the Negev are seen as indicating floodwater irrigation (Mabry 1995; McCreery 2003; Grigson 1995). The presence of canal irrigation has been convincingly argued for the Iron Age period in the Zerqa triangle in the Jordan Valley, based on a relative dense occupation of the area together with the locations of the sites at some distance of water sources and the nature of the topography of the area (Kaptijn 2010).

While there are therefore indications that floodwater irrigation started in the Southern Levant at least in the fourth or third millennium BC (with canal irrigation here probably not starting till later (Ertsen 2010, Kaptijn 2010)), there is no direct evidence for this and additional confirmation by independent methods is needed. Archaeobotanical proxies such as the presence of certain species and seed size, have been used for this purpose (Helbaek 1960; McCreery 2003); however, these are also not without their problems. Although there is a documented correlation between well-watered crops and grain weight and thus size of seeds (Ferrio et al. 2006b), many other factors including environmental variables like temperature, or genotype, charring and the context in which the samples are found, can affect seed size as well, such as other (Rosen and Weiner 1994; Ferrio et al. 2004; Wright 2003; Ferrio et al. 2006b).

Another approach involves the use of characteristics of the weed flora found at a site (functional attributes, such as canopy height and flowering time), which have been shown to differ between irrigated and non-irrigated fields (Jones et al. 2005; Charles et al. 2003). However, scarcity of suitable number of archaeobotanical remains and difficulties associating the right weeds to the right crops in mixed archaeological contexts (see Cappers 2006) might complicate the application of this method.

A relatively new method involves the analysis of phytoliths (plant silicon bodies) as indicators of irrigation. Rosen and Weiner (1994) established a relationship between irrigation and multi-cellular phytoliths in emmer wheat, while Madella et al. (2009) and Jenkins et al. (2011) suggested that there is a relationship between water availability and the ratio of different single celled phytolith types (long cells to short cells) in various species of wheat and barley. While there might be 
problems with using multi-cellular phytoliths as an irrigation indicator due to the possibility of taphonomic breakdown (Jenkins et al. 2011), the use of single cell phytolith ratios seems more promising. However, the research is still ongoing, and it is yet to be demonstrated that the change in fluctuations is applicable to all species of wheat and barley. If this is not the case, then this method is limited because it is not usually possible to accurately identify single celled phytoliths from wheat and barley to species level.

Another promising new approach to discern past water management practices is the use of carbon stable isotope analysis of botanical remains, which is the focus of this paper. Carbon stable isotope ratios in plants are affected by water availability, and are hence used to infer climatic changes (Ferrio et al. 2003). Araus et al. (1997b) and Ferrio et al. (2005) proposed that the same principle can be taken a step further to reconstruct irrigation: when isotopic signals in the archaeological crops indicate wetter conditions than expected from other climate proxies, or when "wetter signals" are measured only in cultivated crops but not in the wild plants, these data are used to argue for water management, such as irrigation or planting in naturally wetter areas such as alluvial fans (Ferrio et al. 2005; Araus et al. 1997b).

\section{Carbon stable isotope analysis of plant remains for environmental reconstruction}

The two stable isotopes (atoms of the same element with a different mass) of carbon are ${ }^{12} \mathrm{C}$ and ${ }^{13} \mathrm{C}$ (Hoefs 1997). These occur in different abundances in nature, but generally with much more of the lighter ${ }^{12} \mathrm{C}$ than ${ }^{13} \mathrm{C}$. The ratio of ${ }^{13} \mathrm{C}$ to ${ }^{12} \mathrm{C}\left({ }^{13} \mathrm{C} /{ }^{12} \mathrm{C}\right.$ or $\left.\delta^{13} \mathrm{C}\right)$ is denoted in parts per mille \%o because of the relatively very small amount of ${ }^{13} \mathrm{C}$ in comparison to ${ }^{12} \mathrm{C}$. Because these isotopes are stable -in contrast to ${ }^{14} \mathrm{C}$ which decays over time and can therefore be used for dating-, the ratio of theoretically stay the same, from when an organism dies to when a sample reaches the laboratory, possibly several thousand years later (Boutton 1991a; Dawson and Brooks 2001; Hoefs 1997).

Plants absorb all their carbon as $\mathrm{CO}_{2}$ from the air. For reasons of energy conservation, they preferentially take up the lighter isotope ${ }^{12} \mathrm{C}$, and discriminate against the heavier ${ }^{13} \mathrm{C}$ (Farquhar et al. 
1982; O'Leary 1981). This results in plant $\delta^{13} \mathrm{C}$ ratios that are more negative than those of air. The actual discrimination is denoted as $\Delta^{13} \mathrm{C}$, and for plants this is their carbon isotope ratio relative to the ratio of $\mathrm{CO}_{2}$ in the air (Ehleringer 1991; O'Leary 1981).

The size of $\Delta$ or the magnitude of discrimination depends for a large part on the photosynthetic pathway of a plant. The main photosynthetic pathways are $\mathrm{C}_{3}$ and $\mathrm{C}_{4}$, named after the number of carbon atoms in their first molecular product after carbon fixation. Most plants indigenous in temperate climates are $\mathrm{C}_{3}$ plants, which comprise almost all trees, and crops like wheat, barley, rice and many of the fruits and vegetables commonly eaten (Boutton 1991b; Sealy 2001). $\mathrm{C}_{4}$ plants are adapted to warm and (semi-)arid environments. Maize has a $\mathrm{C}_{4}$ photosynthetic pathway, as do millet, sugarcane and sorghum (Sealy 2001; Boutton 1991b; Hubick et al. 1990). C $_{3}$ plants discriminate more against ${ }^{13} \mathrm{C}$ than $\mathrm{C}_{4}$ plants do, resulting in lower $\delta^{13} \mathrm{C}$ ratios and larger differences between plant tissues and atmospheric $\mathrm{CO}_{2}$ (larger $\left.\Delta^{13} \mathrm{C}\right)$ (Farquhar et al. 1989; Farquhar 1983; Farquhar et al. 1982; Ehleringer 1991).

In addition to the photosynthetic pathway, the amount of discrimination, especially in $\mathrm{C}_{3}$ plants, can also be affected by environmental factors, for a large part because these might affect photosynthesis (Heaton 1999; Tieszen 1991). Examples are nutrient availability (Heaton 1999; O'Leary 1981; Cabrera-Bosquet et al. 2007), light (Farquhar et al. 1989; Heaton 1999), salinity (Shaheen and Hood-Nowotny 2005), temperature (Tieszen 1991) and water availability (Farquhar and Richards 1984; Farquhar et al. 1989). Genetic differences in carbon isotope discrimination occur between species or groups of species, partly because genetic differences determine how a plant reacts to environmental variation (Tieszen 1991; Heaton 1999).

Because water availability is most limiting to plant growth (Salisbury and Ross 1992), it is thought to be the most important of the environmental factors. The effect on carbon isotope ratios takes place because when soil moisture decreases, plants will (partly) close their stomata, to avoid dehydration. As a result of this, less discrimination of ${ }^{13} \mathrm{C}$ takes place (lower $\Delta^{13} \mathrm{C}$ ) (Farquhar et al. 1989). A positive relationship between increasing aridity and $\Delta{ }^{13} \mathrm{C}$ values of modern plants has been established in several studies. Examples are cereal crops like durum wheat and hulled barley grown in 
greenhouses and fields (Araus et al. 1997a; Araus et al. 1999; Monneveux et al. 2006), trees such as Aleppo pine (Ferrio et al. 2006a), other species such as wheatgrass and sagebrush (Laundré 1999), and leaves of different plant communities over rainfall gradients (Stewart et al. 1995).

Increased evaporation also affects $\Delta^{13} \mathrm{C}$ (Ferrio et al. 2006a), because plants will lose more water, and so do all other factors that affect soil moisture, such as precipitation and irrigation, but also humidity and soil texture (see Farquhar et al. 1989). In addition, nutrient availability is another major factor in plant growth (Cabrera-Bosquet et al. 2007), and, therefore, might be important in determining the amount of carbon isotope discrimination. One of the aims of the research presented here is to establish the relative effects of environmental factors other than water input on carbon isotope discrimination.

\section{Archaeological applications}

Based on the relationship of water availability and plant carbon isotope ratios, carbon stable isotope ratios of ancient plant remains have been used to reconstruct past water availability. A pioneering study by Araus \& Buxó (1993) measured $\Delta{ }^{13} \mathrm{C}$ of archaeological six-row barley and durum wheat kernels from Spain. Apart from changes in atmospheric $\mathrm{CO}_{2}$, one of the possible explanations they gave for the observed change in $\Delta$ over time was a change in aridity (Araus and Buxó 1993). This was further explored by Araus et al. (1997a), and was also used to indicate irrigation practices (Araus et al. 1997b): Carbon isotope discrimination ratios of archaeological grains were compared to modern examples from the same region which received known amounts of water. Differences between ancient and modern assemblages were subsequently ascribed to either changes in climate and/or changes in water management practices. If a ratio is measured that indicates higher water availability than expected from present-day rainfall, it is possible that past climate was wetter. If results suggest higher water availability than is expected from other climate proxies, or as expected from carbon isotope ratios of other (wild) plant species from the same site, a case can be made that artificial irrigation was used on these crops (Araus et al. 1997b; Ferrio et al. 2005). 
The method has been applied to several Mediterranean assemblages, mainly in Spain and Syria, but also in Italy, Jordan and Turkey (Riehl et al. 2008a; Fiorentino et al. 2008; Fiorentino et al. 2010; Ferrio et al. 2005; Ferrio et al. 2006a; Aguilera et al. 2008; Araus et al. 2007; Araus et al. 1999; Araus et al. 1997b; Araus et al. 1997a; Araus and Buxó 1993; Roberts et al. 2011). In the Near East, several sites were studied. Carbon isotope ratios of assemblages of two Neolithic sites, Tell Halula and Akarçay Tepe, along the Middle Euphrates in Syria and Turkey respectively suggested higher water status for the crops than would be expected from present-day rainfall in the region (Araus et al. 1999; Araus et al. 2007). This is in agreement with other climate proxies for the early Holocene (see for example Roberts et al. 2011).

Most other studies in the Near East focused on the Bronze Age. Results from the sites Ebla and Qatna in Syria show several wetter and more arid phases from the fourth to second millennium BC. One of the arid phases was dated between 2200-2040 BC, so simultaneous with the $4.2 \mathrm{ka}$ event (Roberts et al. 2011; Fiorentino et al. 2008). This therefore supports the ability of the method to measure environmental signals. Riehl et al. (2008a) compared crops of eight sites in Syria and northern Jordan and found carbon isotope ratios indicating increased aridity from the Early Bronze Age to the Middle Bronze Age. This is again supported by other climate proxies (Riehl et al. 2008b; Riehl 2008).

A possible advantage of using carbon stable isotope analyses of archaeobotanical remains instead of -or preferably together with- other climate proxies, is that the method can potentially show site-specific environmental changes. For example, for the different sites in Syria, some, such as Tell Mozan and Emar, show increased water stress from the Early to Middle Bronze Age, whereas this was much less the case for Qatna (Riehl et al. 2008a). Climate proxies of off-site records might not have this site-specific resolution.

The use of the method for reconstruction of irrigation practices has mainly been applied to archaeological sites in Spain, first by Araus et al. (1997b) to assemblages from Southeast Spain. They first established reference values for $100 \%$ rain-fed and irrigated durum wheat and barley grains from the analysis of modern crops grown under known watering regimes and used these data also to 
develop a regression equation for the estimation of absolute water-input during grain-filling from the carbon isotope composition of plant remains. These reference values were then compared to those of archaeological samples. Because barley and wheat grains from the archaeological (Neolithic to Iron Age) sites were generally most consistent with the reference values for the rain-fed samples, it was concluded that no irrigation of cereals had taken place, although a few examples with higher ratios were taken to possibly indicate cultivation in naturally wetter areas (Araus et al. 1997b). ${ }^{4}$

While Araus et al. (1997b) did not distinguish between water input by rainfall or irrigation, Ferrio et al. (2005) proposed to compare the isotopic composition of wild plants (which would in all likelihood not have been irrigated) with those of cultivated crops for this purpose. They tested their hypothesis by comparing barley and wheat carbon isotope ratios of archaeological grains from Northeast Spain with published values for wood charcoals from Southeast France (as found in Vernet et al. 1996). As they found the isotope values of both groups relatively similar, they concluded that no irrigation had taken place (Ferrio et al. 2005).

\section{Exploring the influence of water input and other environmental factors on carbon stable isotope composition}

The application of carbon stable isotope analysis of cereal remains in archaeology is relatively new, and while the general principles are well established, there are still a number of issues to be addressed in order to refine the method and to better interpret variations in the data. One problem is, for example, the question of how wide a variation of carbon isotope values we might expected from a sample of cereals grown with roughly the same water input over consecutive years at the same site or between different sites. In addition, in order to confidently apply the method to archaeological samples, we must also explore possible effects on isotopic values of taphonomic processes and charring, although this falls outside the scope of this paper (but see Marino and DeNiro 1987; Araus

\footnotetext{
${ }^{4}$ It was also found that based on carbon isotope discrimination faba beans, in contrast to cereals, might have been irrigated (Araus et al. 1997b).
} 
et al. 1997b). The research presented here is part of an ongoing project specifically designed to address these problems in the environmental context of the Southern Levant, mainly through analyses of modern cereals specifically grown for the purpose of testing methodological approaches to the reconstruction of water management in archaeology (Mithen et al. 2008; Jenkins et al. 2011). As the results of a pilot study involving the experimentally grown wheat have been published already by Stokes et al. (2011), this paper will discuss preliminary results of barley and sorghum samples from these experiments.

\section{Crop growing experiments}

In order to test the relationship between water availability and both phytoliths and plant stable isotope ratios in modern cereals, crops were experimentally grown as part of the University of Reading's Water, Life, and Civilisation project in cooperation with NCARE (National Centre for Agricultural Research and Extension, based in Jordan) (Mithen et al. 2008; Jenkins et al. 2011). Native landraces of durum wheat (Triticum turgidum ssp. durum, ACSAD 65) and six-row barley (Hordeum vulgare, ACSAD 176) were raised over three consecutive years at three different crop growing stations in Jordan: Deir 'Alla, Ramtha and Khirbet as-Samra (fig. 1). In addition, sorghum (Sorghum bicolor) was grown at Deir 'Alla, Ramtha and at the farm of Sameeh Nuimat near Salt.

Although all of these sites are in northern Jordan, they nonetheless differ significantly in their micro-environments (table 1). Deir 'Alla is located in the Jordan Valley, at around 200m below sea level, whereas Ramtha and Khirbet as-Samra are situated on the Jordan Plateau at $c .510 \mathrm{~m}$ and $c$. 560m above sea level respectively (Carr 2009; Stokes 2008). Ramtha usually receives most rainfall and Khirbet as-Samra the least, although in two of the years the experiments took place (2005-2006 and 2006-2007 growing seasons), rainfall at Deir 'Alla was highest. Except for the sorghum growing experiments at the farm near Salt, environmental conditions such as rainfall, evaporation, temperature, and relative humidity were closely monitored, so that their effects on the crops' carbon isotope ratios can be established. 
Wheat and barley were grown for three consecutive seasons, from 2005 to 2008, each year planted in November/December and harvested in May. The crops were grown in 5 x 5 m plots, with $1.5 \mathrm{~m}$ in between each plot. They received different amounts of water. In the first growing season four different irrigation regimes were used: $0 \%$ (rainfall only), $80 \%, 100 \%$, and $120 \%$ of the crops' optimum water requirements (fig. 2). The latter were based on FAO standards using the Pan Evaporation method and were calculated on a weekly basis, taking into account rainfall, evaporation, and estimated relative humidity, temperature and wind speed (Allen et al. 1998, Khalil Jamjoum pers. comm.). ${ }^{5}$ In the second and third growing seasons $40 \%$ plots were added for both crops. In all cases a drip irrigation system was used. Plots received an additional initial water supply of $25 \mathrm{~mm}$ directly after planting to encourage germination. No fertilizer or pesticides were used and no weeding was conducted. Sorghum was grown in a similar way (under the five different irrigation regimes) in 2009 and 2010, but was sown in April and harvested in September/October.

For a more detailed description of irrigation and harvesting strategies see Mithen et al. (2008) and Jenkins et al. (2011).

\section{Isotopic analyses}

For this study samples were taken from each irrigation regime for every year at every site. For every plot three samples of ten grains each were analysed for their stable carbon isotope composition. Samples of 10 grains each were analysed, as it had been previously established that at least 7 grains are needed to average out any intra-plant and intra-plot variation (Stokes 2008, unpublished MSc thesis), as also confirmed by another study, which cite using six measurements of the same species within one sample (Riehl et al. 2008a). For every barley and every sorghum plot three samples were

\footnotetext{
${ }^{5}$ The amount of irrigation was based on rainfall and the crops' $\mathrm{ET}_{\mathrm{c}}$, which is 'crop evapotranspiration under standard conditions' (Allen et al. 1998), which was calculated as follows: $\mathrm{ET}_{\mathrm{c}}=\mathrm{K}_{\mathrm{c}} \times \mathrm{K}_{\mathrm{p}} \times \mathrm{K}_{\mathrm{r}}$ / irrigation effect, in which $\mathrm{K}_{\mathrm{c}}$ is the 'crop coefficient', differing for different growing stages; $\mathrm{K}_{\mathrm{p}}$ is the 'pan coefficient', which depends on wind speed, temperature and humidity, here 0.7 ; and $\mathrm{K}_{\mathrm{r}}$ the 'soil evaporation reduction coefficient', here 1.0. The irrigation effect, for which 90\% (0.9) was used, was only taken into account in the 2006-2007 and 2007-2008 growing seasons (NCARE Khalil Jamjoum pers. comm., based on Allen et al. 1998, definitions from Allen et al. 1998).
} 
analyzed, for which grains spread over the plots were used. Because of the possibility of an edge effect in small plots (Austin and Blackwell 1980), no samples from the outer 50cm were used. The latter relates to experiments with small plot cereal yield trials in which it was found that the yield of outer rows of a plot are higher than in the middle of a plot, which for small plots might thus distort the results (Austin and Blackwell 1980). To rule out any intra-plot variation grains were chosen from different parts of each plot, which was harvested in a $50 \mathrm{~cm}$ grid (Jenkins et al. 2011).

Samples were washed in de-ionised water, freeze-dried, and homogenised and ground with a mortar and pestle. Subsequently $\sim 1 \mathrm{mg}$ of each sample was weighed into tin capsules and analysed in duplicates in a Europa 20-20 isotope ratio mass spectrometer coupled to a Sercon elemental analyser at the Department of Archaeology, University of Reading. The analytical error was $0.1 \%$ or smaller $(1 \sigma)$

$\Delta{ }^{13} \mathrm{C}$ was calculated using the formula $\Delta{ }^{13} \mathrm{C}=\left(\delta^{13} \mathrm{C}_{\text {air }}-\delta^{13} \mathrm{C}_{\text {sample }}\right) /\left(1+\delta^{13} \mathrm{C}_{\text {sample }} / 1000\right)$, as $\Delta$ is the actual discrimination of the plant (the sample) relative to the air. $-8.00 \%$ was taken for $\delta^{13} C_{\text {air }}$.

\section{Statistical analyses}

For statistical t-tests, regression analysis and ANOVA the Genstat $12^{\text {th }}$ edition software was used.

\section{Results and discussion}

$\Delta^{13} \mathrm{C}$ of barley grains and water availability

The results indicate that, as expected, a positive logarithmic relationship exists between water input and carbon isotope discrimination $\Delta^{13} \mathrm{C}$ in barley grains, although the coefficient of determination is only moderately high $\left(r^{2}=0.53\right)$ (fig. 3). Even though differences in the average values of cereals from the $0 \%$ irrigation regime on the one hand and the $80 \%, 100 \%$, and $120 \%$ irrigation regimes on the other hand are statistically significant (Genstat ANOVA using contrasts, $\mathrm{p}<0.001$ ), there is also significant overlap in the values obtained for individual samples from the rain-fed only samples with those of the others. This pattern is the same when absolute water input (rainfall + irrigation) during 
the total growing season instead of irrigation regime is plotted (fig. 4). When one or two possible outliers with respectively unexpectedly low and unexpectedly high $\Delta^{13} \mathrm{C}$ are removed, the relationship does become stronger $\left(\mathrm{r}^{2}=0.68\right.$ when both 'outliers' are not taken into account), but variation remains very high. This suggests that it might be difficult to confidently distinguish between crops that received no additional water and those that were irrigated, when sample sizes are small.

The logarithmic nature of the relationship is in agreement with results found by Araus et al. (1997b) for modern barley grains in Spain. It implies that grains grown under very different amounts of water might have only a slight difference in their $\Delta{ }^{13} \mathrm{C}$ (Araus et al. 1997b), especially for the higher amounts of water. For irrigation regime, it can be noted that only slight (insignificant) differences are present between the $80 \%, 100 \%$, and $120 \%$ regimes. For Deir 'Alla, and to a lesser extent Ramtha, differences between the $40 \%$ regime and the $80 \%, 100 \%$, and $120 \%$ regimes are not large either. The evening out of data points at higher amounts of water is probably caused by water availability being less limiting in carbon isotope discrimination. Around $250-300 \mathrm{~mm}$ is generally the accepted minimum amount of annual rainfall required for stable dry-farming of crops (Charles et al. 2003), and it is therefore not unexpected that from around these amounts of water input more carbon isotope discrimination takes place: the plant now can open its stomata fully again, and will have the opportunity to discriminate more against ${ }^{13} \mathrm{C}$ than when less water was present (Farquhar et al. 1989). ${ }^{6}$ The fact that in some cases water is already no longer limiting at $40 \%$ is probably caused by high amounts of rainfall during some parts of the growing season. Because the experiments took place outside, in a natural field setting, it was not possible to water the plants with less than the amount of rainfall, and plants would still need to receive irrigation in later, drier parts of the season in order for them to survive.

Because grains only form and ripen during the latter part of the growing season (the grain filling period), other studies have used water input during this period to establish a relationship with $\Delta{ }^{13} \mathrm{C}$ (as in Araus et al 1997a; Araus et al. 1997b). Indeed carbon in grains is said to derive mainly

\footnotetext{
${ }^{6}$ Plots receiving much more than $250-300 \mathrm{~mm}$ generally are the $100 \%$ and $120 \%$ plots. In addition, at Deir 'Alla almost $100 \mathrm{~mm}$ of rain fell at the end of the 2005-2006 growing season, leading to a high overall water input for that season there.
} 
from photosynthesis occurring during grain filling (Fageria et al. 2006). If for our data from Jordan instead of the water input during the total growing season, only the water input during the grain filling period is taken, again no strong relationship is present (fig. 5). ${ }^{7}$ Surprisingly, the relationship is even less strong than for water input during the total growing season. It is possible that water is brought over from earlier in the season and that this does affect grain isotopic ratios. Alternatively, carbon isotopes that were fixed by the plant in an earlier part of the growing season might be used for the grains, perhaps especially when plants are under stress.

\section{Inter-site variation}

While the relationship between water availability and carbon isotope discrimination for all three sites together was only moderate, with a wide spread of individual data-points, a much stronger relationship exists between irrigation regime and $\Delta^{13} \mathrm{C}$ for individual sites on their own $\left(\mathrm{r}^{2}=0.74\right.$ for Deir 'Alla, 0.83 for Ramtha and 0.84 for Khirbet as-Samra, fig. 6). As in the combined data-set, the nature of the relationship is a logarithmic one and as in the combined data-set no significant differences are present between the $80 \%, 100 \%$ and $120 \%$ regimes. However, differences between the sites exist, such as the relative higher values for the $40 \%$ regimes at Deir "Alla and Ramtha (as discussed above).

In terms of water input, the relationship is stronger within each site for Ramtha and Khirbet as-Samra than it is in general, although this is not the case for Deir 'Alla (fig. 7). The extremely weak relationship between water input and $\Delta{ }^{13} \mathrm{C}$ of barley grains at Deir 'Alla is probably caused by interannual variation of $\Delta^{13} \mathrm{C}$ at this site (as discussed into more detail below). In any case, it is partly caused by the 'outliers' also discussed above. It is not completely clear what causes these $\Delta^{13} \mathrm{C}$ values to be so different, but interestingly they do both represent values from the rainfall-only $(0 \%)$ irrigation

\footnotetext{
${ }^{7}$ The grain filling period was determined as matching the harvest stage, which was established according to FAO guidelines (Doorenbos and Pruitt 1977; Allen et al. 1998) and observations in the field. This stage corresponds to the last part of the growing season, and generally consists of the month April and part of May. In addition, a relationship was established for water input for the period of 40 days before irrigation was stopped, which is when most carbon will have been deposited in the grains.
} 
regime. In addition, if the Deir 'Alla data would be completely taken out, and thus only values from the Jordanian plateau sites would be used, a much stronger relationship would be present than with the Deir 'Alla data included $\left(r^{2}=0.70\right)$. In any case, the relationship for every site separate is stronger than the overall relationship, which is true for water input in both the total growing season and the grain filling period only. It can thus be concluded that there is significant inter-site variation in the $\Delta^{13} \mathrm{C}$ of the analysed barley grains. This would make a direct comparison between absolute $\Delta^{13} \mathrm{C}$ values of different sites complicated.

The clear differences between the sites were not necessarily anticipated, given that they are all situated relatively close together (at most $57 \mathrm{~km}$ apart as the crow flies) in the north of Jordan. The sites do have different micro-climates, and indeed different environmental factors can affect carbon isotope composition. As discussed above, differences in light or irradiance, nutrient availability, temperature, salinity or altitude are all known to have at least small effects on the ability of $\mathrm{C}_{3}$ plants to discriminate effectively against ${ }^{13} \mathrm{C}$ during photosynthesis (Farquhar et al. 1989; Heaton 1999; O'Leary 1981; Shaheen and Hood-Nowotny 2005; Tieszen 1991; Körner et al. 1988; Körner et al. 1991). Nevertheless, during preliminary analysis, altitude, temperature, relative humidity, number of rain days and salinity could not conclusively explain the magnitude of inter-site variation observed here (neither on their own, nor in combination with water input, nor in combination with other factors). Specifically, it is curious that, although the environments at Khirbet as-Samra and Ramtha are much more similar to each other than to Deir 'Alla, which is situated at significantly lower altitude and with higher annual temperatures and lower humidity than the other two (table 1), the isotope data from crops grown at these sites are actually most similar between Ramtha and Deir "Alla, while the $\Delta$ values observed at Khirbet as Samra are notably smaller than at the other two sites. Temperature for example is markedly higher at Deir "Alla, but does not differ much between the two other sites - if temperature would affect $\Delta^{13} \mathrm{C}$ values in a systematic way, it would be expected that $\Delta^{13} \mathrm{C}$ would be different at Deir 'Alla but similar at Ramtha and Khirbet as-Samra.

The only environmental factor that is consistently different between all three sites is rainfall. It is probably no coincidence that grains from the site with the lowest rainfall over the study period, 
Khirbet as-Samra, return the smallest $\Delta{ }^{13} \mathrm{C}$, while those from Deir 'Alla, the site with most rainfall, at least in the two seasons 2005-2007, have generally the highest $\Delta^{13} \mathrm{C}$. It seems therefore that rainfall, on top of the effect of irrigation regime, has an additional effect on $\Delta^{13} \mathrm{C}$, as confirmed by statistical analysis (ANOVA, fitted together with irrigation regime rainfall has $\mathrm{p}=0.009$ ). The effect of rainfall is probably caused by the fact that in contradiction to irrigation, which can be controlled, rain will fall unpredictably and might fall suddenly in heavy outbursts, causing a temporary overwatering of the crops. If this would happen more often at one site than another (as was the case here), this might cause differences in isotopic composition of the crops.

However, water input (irrigation regime and rainfall) does not explain all variation. It is probable that a complex interplay of different factors determining how much water actually reach the plant play a role as well. These partly are the factors that were taken into account when calculating the crops' water requirements, which are water input, evaporation (and thus indirectly temperature and humidity), and estimated mean humidity, temperature and wind speed; but also the nature of the rainfall -whether it fell in heavy outbursts in large quantities at once, or in smaller amounts spread over a longer period. Rainfall also means that clouds are present, which causes a decrease in light intensity, so different rainfall patterns at different sites might in this way cause an additional discrepancy. In addition, soil characteristics such as soil texture and soil depth can affect the amount of water actually available to plants. These factors almost certainly have an effect, although we are not at the moment able to explain the exact way in which this takes place.

These results are supported by a recent study of durum wheat in Greece, in which Heaton et al. (2009) attributed differences between $\Delta^{13} \mathrm{C}$ between different sites to differences in variables affecting water availability (Heaton et al. 2009). They measured differences of around $2 \%$ for sites $35 \mathrm{~km}$ apart and of up to $3.2 \%$ for sites 'several hundred kilometres apart'. This is in agreement with this study, where differences between barley grain $\Delta^{13} \mathrm{C}$ were often up to $2-3 \%$ otween different sites. In addition, when comparing our data to those of earlier published results of barley grown in Spain (Araus et al. 1997b) (fig. 5), it appears that plants receiving similar amounts of water during grain filling have generally higher $\Delta^{13} \mathrm{C}$ values in Jordan than in Spain. It seems likely that these 
differences are also at least partly caused by differences in environmental factors other than water input.

Inter-annual variation

Although the results for the 2005-2006 growing season are generally slightly lower, there is overall no significant difference between the different years when looking at data for irrigation regime. However, for the $0 \%$ regime especially there is significant variation for Deir 'Alla, with almost $2 \%$ o difference on average between the first and the last growing season. It are also these values - the $0 \%$ value of the 2005-2006 and the 0\% value of the 2007-2008 season of Deir 'Alla- that are the obvious outliers of the regression line of $\Delta^{13} \mathrm{C}$ as a result of water input (as discussed above, see figs 4 and 6). These deviating values are possibly caused by differences in rainfall between the different years, as in the first growing season Deir 'Alla received in total almost $300 \mathrm{~mm}$, in the second this was reduced till c. $220 \mathrm{~mm}$ and in the last growing season only just over $100 \mathrm{~mm}$ fell. Rainfall during grain filling varied between the years at Deir 'Alla in a similar way. The other two sites had a more consistent rainfall pattern over the three growing seasons of barley (at Ramtha this was between $159 \mathrm{~mm}$ and $175 \mathrm{~mm}$ over the three years and at Khirbet as-Samra between 75 and $92 \mathrm{~mm}$, see table 1). Seasonal distribution of rainfall was different between the different years as well: In the last two years most rain fell in the winter months, as expected, but in the first year rainfall was highest towards the end of the season. This was the case at all three sites, but was especially pronounced at Deir 'Alla. Interestingly though, when most rain fell, the $\Delta^{13} \mathrm{C}$ values at Deir 'Alla were lowest, whereas this would be expected to be the other way around. Therefore, rainfall differences alone do not explain the inter-annual variation. Again, it is likely that it is caused by several different factors affecting water availability. Heaton et al. (2009) also found inter-annual differences in their study of durum wheat grains in Greece: between some years they found variation as large as $2.7 \%$, while between other years there were no differences. This is in agreement with the results presented here, although we have only found small differences. 
Wheat and barley

Interestingly, the relationship between $\Delta{ }^{13} \mathrm{C}$ and irrigation regime for wheat from the same experiment, described by Stokes et al. (2011), similarly shows only a moderate general relationship but strong site-specific relationships. For wheat, the differences between the sites are even more pronounced (Stokes et al. 2011). Whereas for barley the values for Deir 'Alla and Ramtha are not very far apart, for wheat there is a pronounced difference between all the sites. Furthermore, the nature of the relationship seems different between barley and wheat, especially at Ramtha, but also at Khirbet as-Samra, as the values for the barley tend to even out earlier than those for the wheat. These differences between wheat and barley are probably caused by a difference in growing cycle between the two crops. In the Mediterranean and Near East the wet season is mainly in winter, and the dry season starts in April/May. As barley has a shorter growing cycle, it will often have ripened before the dry season starts, whereas wheat, when planted at the same date as the barley (as was the case in our crop growing experiments), might still be ripening and thus experience more drought stress than barley (Riehl et al. 2008a), leading to different $\Delta^{13} \mathrm{C}$.

$\Delta \Delta^{13} \mathrm{C}$ of sorghum grains and water availability

The results for the 2009 growing season for all three sites indicate that for sorghum no relationship between water availability and carbon isotope discrimination of the grains is present, although it must be noted that no rainfed-only (0\%) samples could be analysed from any of the sites, since no grains developed in these plots. Although small in absolute terms, significant differences between the different sites were present again (fig. 8) (one-sided t-test $\mathrm{p}<0.001$ ). In addition to grain, chaff was also analysed for one of the sites, Deir 'Alla; however, again no relationship between $\Delta^{13} \mathrm{C}$ and $40 \%$ $120 \%$ irrigation regime was observed.

It therefore seems that there is no relationship between water availability and carbon isotope composition of different anatomical parts of sorghum plants. This is not completely unexpected, because as a crop with a $\mathrm{C}_{4}$ photosynthetic pathway, sorghum discriminates less against ${ }^{13} \mathrm{C}$ during photosynthesis (Farquhar et al. 1989; Farquhar 1983; Farquhar et al. 1982; Ehleringer 1991), and is 
better adapted to arid environments. Moreover, in the $\mathrm{C}_{4}$ pathway changes in stomatal conductance are not directly reflected in the amount of discrimination taking place (Farquhar et al. 1983; Farquhar et al. 1989), so that when a plant partly closes its stomata as a reaction to increasing aridity, this will not directly affect $\Delta^{13} \mathrm{C}$. Therefore, we would expect only a small, if any, reaction to increasing aridity (Codron et al. 2005; Hattersley 1982). A study of African savannah plants for example did find small differences of about $1 \%$ for $\mathrm{C}_{4}$ plants receiving lower and higher rainfall (compared to differences of $2 \%$ for $\mathrm{C}_{3}$ plants) (Codron et al. 2005).

\section{Conclusion}

Implications for archaeological application of the method

The results presented here suggest that it is possible to use carbon stable isotope analyses of archaeological cereal remains for the reconstruction of past water availability, although with some limitations. First, it appears that this method can only be used for $\mathrm{C}_{3}$ species of plants as evidenced by our results which demonstrate that the $\mathrm{C}_{4}$ plant sorghum, at least, does not respond. Nevertheless, it would be desirable to confirm these results with samples grown without irrigation, and possibly with other $\mathrm{C}_{4}$ species. Second, although a general relationship does exist between water availability and $\Delta{ }^{13} \mathrm{C}$ of barley (and wheat) grains, this relationship seems to be site-specific, and at least has a large variability, and therefore extreme caution should be applied when directly comparing $\Delta \Delta^{13} \mathrm{C}$ of grains from different sites, as has sometimes been done in the literature. Caution should especially be exercised in areas, such as the Southern Levant, where sites might have very different micro-climates, even though they may only be small distances apart. In addition, within a site, the values might differ between years. When archaeological sites are studied, a large enough sample size should therefore be taken to rule out as much as possible inter-site and inter-annual variation.

Because the relationship between $\Delta{ }^{13} \mathrm{C}$ and water availability for the pooled samples is not particularly strong, using the values obtained here as a baseline for archaeological samples from all of the north of Jordan would be problematic. It might be more feasible to create a baseline for samples of 
sites with similar environmental settings - if for example only the data from the Jordanian plateau, so of sites Ramtha and Khirbet as-Samra would be used, a relatively strong relationship between water input and $\Delta^{13} \mathrm{C}$ would be present, although still with a large variation. Also, because of the relatively wide spread of data, both when calculated for the total growing season and for the grain filling stage, it does not seem useful in this case to use the data as basis for a regression analysis to calculate total water input from the observed $\Delta{ }^{13} \mathrm{C}$ values (as suggested by Araus et al. 1997b) - the error associated with such determinations would simply be too large. Although the large error is for a part caused by certain outliers, it would be difficult to establish for archaeological samples whether or not these would represent such outliers, especially not as we have not yet been able to specify the causes for the occurrence of these unexpectedly low or high values.

It seems that it may be possible to use the method for a relative measure of wetter and drier periods within a site, although a sufficiently large number of samples needed to be studied to overcome the problem of possible inter-annual variation. Still, even though, the inter-site and interannual variation may distort the environmental signal, the results presented here demonstrate that they do not obscure it completely. Also, geographic and yearly differences can be used for other purposes: Heaton et al. (2009) even use the measured geographic and inter-annual differences to determine if archaeological grains from the Greek site Assiros Toumba derived from single harvests or not and if these were local. Furthermore, it is possible that when these issues are studied in more detail, and are better understood, it might be able to account for them, and the method could then more easily be used to compare different sites.

\section{Further research}

The results presented here are part of an ongoing study. Sorghum has been grown in 2010 as well, and more data from this $\mathrm{C}_{4}$ crop will thus follow. Other current and future work consists of nitrogen stable isotope analyses, which have been shown to possibly correlate to water availability and which moreover might give insights into nutrient status of the plants (Aguilera et al 2008). In addition, 
charring and burial experiments are being conducted, to assess possible effects of charring and soil processes on the isotopic composition of the cereals.

\section{Acknowledgements}

PF is funded by a University of Reading PhD studentship. Travel to Jordan in 2009 was made possible by a Council for British Research in the Levant (CBRL) Travel Grant. The Water, Life, and Civilization project was funded by the Leverhulme Trust. We are very grateful to the Water, Life, and Civilization project for supplying the barley samples; to Khalil Jamjoum (National Centre for Agricultural Research and Extension) and Sameeh Nuimat for conducting the crop growing experiments in Jordan; to CBRL in Amman for help with the crop growing experiments; to Tina Moriarty for advice on and help with sample processing; to Sam Smith and David Mudd \& students for taking many of the samples from Jordan to the UK; and to Karin Schuitema and both reviewers for their very helpful comments on this paper.

\section{Bibliography}

Aguilera M, Araus JL, Voltas J, Rodríguez-Ariza MO, Molina F, Rovira N, Buxó R, Ferrio JP (2008) Stable carbon and nitrogen isotopes and quality traits of fossil cereal grains provide clues on sustainability at the beginnings of Mediterranean agriculture. Rapid Communications in Mass Spectrometry 22:1653-1663. doi:10.1002/rcm.3501

Akkermans PMMG, Schwartz GM (2003) The Archaeology of Syria: From Complex HunterGatherers to Early Urban Societies (ca. 16,000-300BC). Cambridge University Press, Cambridge

Akkermans PMMG, van der Plicht J, Nieuwenhuyse OP, Russell A, Kaneda A, Buitenhuis H (2010) Weathering climate change in the Near East: dating and Neolithic adaptations 8200 years ago. Antiquity Project Gallery 325 
Allen RG, Pereira LS, Raes D, Smith M (1998) Crop Evapotranspiration - Guidelines for Computing Crop Water Requirements. FAO Irrigation and drainage paper 56, FAO, Rome

Araus JL, Buxó R (1993) Changes in Carbon Isotope Discrimination in Grain Cereals from the NorthWestern Mediterranean Basin during the Past Seven Millennia. Australian Journal of Plant Physiology 20:117-128

Araus JL, Febrero A, Buxó R, Camalich MD, Martín D, Molina F, Rodríguez-Ariza MO, Romagosa I (1997a) Changes in carbon isotope discrimination in grain cereals from different regions of the western Mediterranean Basin during the past seven millennia. Palaeoenvironmental evidence of a differential change in aridity during the late Holocene. Global Change Biology 3:107-118

Araus JL, Febrero A, Buxó R, Rodríguez-Ariza MO, Molina F, Camalich MD, Martín D, Voltas J (1997b) Identification of Ancient Irrigation Practices based on the Carbon Isotope Discrimination of Plant Seeds: a Case Study from the South-East Iberian Peninsula. Journal of Archaeological Science 24:729-740

Araus JL, Febrero A, Catala M, Molist M, Voltas J, Romagosa I (1999) Crop water availability in early agriculture: evidence from carbon isotope discrimination of seeds from a tenth millennium BP site on the Euphrates. Global Change Biology 5:201-212

Araus JL, Ferrio JP, Buxó R, Voltas J (2007) The historical perspective of dryland agriculture: lessons learned from 10000 years of wheat cultivation. Journal of Experimental Botany 58 (2):131145

Austin RB, Blackwell RD (1980) Edge and neighbour effects in cereal yield trials. Journal of Agricultural Science 94:731-734

Bastert K, Lamprichs R (2004) The Wadi Qattar Catchment Area: Ancient Techniques of Water Use and Storage. An Archaeological Perspective. In: Bienert H-D, Häser J (eds) Men of Dikes and Canals: The Archaeology of Water in the Middle East. Verlag Marie Leidorf, Rahden, pp 5763 
Bellwald U, al-Huneidi M (2003) The Petra Siq: Nabataean Hydrology Uncovered. Petra National Trust, Amman

Betts AVG (ed) (1991) Excavations at Jawa 1972-1986: Stratigraphy, Pottery and Other Finds. Excavations and Explorations in the Hashemite Kingdom of Jordan. Edinburgh University Press, Edinburgh

Bienert H-D, Häser J (eds) (2004) Men of Dikes and Canals: The Archaeology of Water in the Middle East. Verlag Marie Leidorf, Rahden

Bourke SJ (2008) The Chalcolithic Period. In: Adams RB (ed) Jordan: An Archaeological Reader.

Boutton TW (1991a) Stable Carbon Isotope Ratios of Natural Materials: I. Sample Preparation and Mass Spectrometric Analysis. In: Coleman DC, Fry B (eds) Carbon Isotope Techniques. Academic Press, San Diego, pp 155-171

Boutton TW (1991b) Stable Carbon Isotope Ratios of Natural Materials: II. Atmospheric, Terrestrial, Marine, and Freshwater Environments. In: Coleman DC, Fry B (eds) Carbon Isotope Techniques. Academic Press, San Diego, pp 173-185

Braemer F, Genequand D, Maridat CD, Blanc PM, Dentzer JM, Gazagne D, Wech P (2009) Longterm management of water in the Central Levant: the Hawran case (Syria). World Archaeology 41 (1):36-57

Butzer KW (1996) Irrigation, raised fields and management: Wittfogel redux? Antiquity 70:200-204

Cabrera-Bosquet L, Molero G, Bort J, Nogués S, Araus JL (2007) The combined effect of constant water deficit and nitrogen supply on WUE, NUE and $\Delta^{13} \mathrm{C}$ in durum wheat potted plants. Annals of Applied Biology 151:277-289

Cappers RTJ (2006) The reconstruction of agricultural practices in ancient Egypt: an ethnoarchaeobotanical appriach. Palaeohistoria 47/48:429-446

Carr G (2009) Water reuse for irrigated agriculture in Jordan. Unpiblished PhD thesis, University of Reading. 
Charles M, Hoppé C, Jones G, Bogaard A, Hodgson JG (2003) Using weed functional attributes for the identification of irrigation regimes in Jordan. Journal of Archaeological Science 30:14291441

Codron J, Codron D, Lee-Thorp JA, Sponheimer M, Bond WJ, Ruiter Dd, Grant R (2005) Taxonomic, anatomical, and spatio-temporal variations in the stable carbon and nitrogen isotopic compositions of plants from an African savanna. Journal of Archaeological Science $32: 1757-1772$

Davies M (2009) Wittfogel's dilemma: heterarchy and ethnographic approaches to irrigation management in Eastern Africa and Mesopotamia. World Archaeology 41 (1):16-35

Dawson TE, Brooks PD (2001) Fundamentals of Stable Isotope Chemistry and Measurement. In: Unkovich M, Pate J, McNeill A, Gibbs DJ (eds) Stable Isotope Techniques in the Study of Biological Processes and Functioning of Ecosystems. Kluwer Academic Publishers, Dordrecht, pp 1-18

deMenocal PB (2001) Cultural Responses to Climate Change During the Late Holocene. Science 292:667-673

Doorenbos J, Pruitt WO (1977) Guidelines for predicting crop water requirements, vol 24. FAO Irrigation and Drainage paper. FAO, Rome

Ehleringer JR (1991) ${ }^{13} \mathrm{C} /{ }^{12} \mathrm{C}$ Fractionation and Its Utility in Terrestrial Plant Studies. In: Coleman DC, Fry B (eds) Carbon Isotope Techniques. Academic Press, San Diego, pp 187-200

Ertsen MW (2010) Structuring properties of irrigation systems: understanding relations between humans and hydraulics through modelling. Water History 2:165-183

Fageria NK, Baligar VC, Clark RB (2006) Physiology of Crop Production. Food Products Press, New York

Farquhar GD (1983) On the Nature of Carbon Isotope Discrimination in $\mathrm{C}_{4}$ Species. Australian Journal of Plant Physiology 10:205-226

Farquhar GD, Ehleringer JR, Hubick KT (1989) Carbon Isotope Discrimination and Photosynthesis. Annu Rev Plant Physiol Plant Mol Biol 40:503-537 
Farquhar GD, O'Leary MH, Berry JA (1982) On the Relationship between Carbon Isotope Discrimination and the Intercellular Carbon Dioxide Concentration in Leaves. Australian Journal of Plant Physiology 9:121-137

Farquhar GD, Richards RA (1984) Isotopic Composition of Plant Carbon Correlates with Water-use Efficiency of Wheat Genotypes. Australian Journal of Plant Physiology 11:539-552

Ferrio JP, Alonso N, López JB, Araus JL, Voltas J (2006a) Carbon isotope composition of fossil charcoal reveals aridity changes in the NW Mediterranean Basin. Global Change Biology 12:1253-1266. doi:10.111/j.1365-2486.2006.01170.x

Ferrio JP, Alonso N, Voltas J, Araus JL (2004) Estimating grain weight in archaeological cereal crops: a quantitative approach for comparison with current conditions. Journal of Archaeological Science 31:1635-1642

Ferrio JP, Alonso N, Voltas J, Araus JL (2006b) Grain weight changes over time in ancient cereal crops: Potential roles of climate and genetic improvement. Journal of Cereal Sciences 44:323332

Ferrio JP, Araus JL, Buxó R, Voltas J, Bort J (2005) Water management practices and climate in ancient agriculture: inferences from the stable isotope composition of archaeobotanical remains. Vegetation History and Archaeobotany 14:510-517

Ferrio JP, Voltas J, Araus JL (2003) Use of carbon isotope composition in monitoring environmental changes. Management of Environmental Quality: An International Journal 14 (1):82-98

Finlayson B, Lovell J, Smith S, Mithen S (2011) The archaeology of water management in the Jordan Valley from the Epipalaeolithic to the Nabathaean, 21,000 BP (19000 BC) to AD 106. In: Mithen S, Black E (eds) Water, Life, and Civilisation: Climate, Environment and Society in the Jordan Valley. Cambridge University Press, Cambridge, pp 191-217

Fiorentino G, Caracuta V, Calcagnile L, D'Elia M, Matthiae P, Mavelli F, Quarta G (2008) Third millennium B.C. climate change in Syria highlighted by Carbon stable isotope analysis of ${ }^{14}$ C-AMS dated plant remains from Ebla. Palaeogeography, Palaeoclimatology, Palaeoecology 266:51-58 
Fiorentino G, Caracuta V, Volpe G, Turchiano M, Quarta G, D'Elia M, Calcagnile L (2010) The first millennium AD climate fluctuations in the Tavoliere Plain (Apulia, Italy): New preliminary data from the ${ }^{14} \mathrm{C}$ AMS-dated plant remains from the archaeological site of Faragola. Nuclear Instruments and Methods in Physics Research B 268:1084-1087

Fujii S (2007) PPNB barrage systems at Wadi Abu Tulayha and Wadi ar-Ruwayshid ash-Sharqi: A preliminary report of the 2006 spring field season of the Jafr Basin Prehistoric Project, phase 2. ADAJ 51:403-427

Fujii S (2008) Wadi Abu Tulayha: A preliminary report on the 2007 summer field season of the Jafr Basin Prehistoric Project, phase 2. ADAJ 52:445-479

Galili E, Nir Y (1993) The submerged Pre-Pottery Neolithic water well of Atlit-Yam, northern Israel, and its palaeoenvironmental implications. The Holoceneq 3 (3):265-270

Garfinkel Y, Vered A, Bar-Yosef O (2006) The domestication of water: the Neolithic well at Sha'ar Hagolan, Jordan Valley, Israel. Antiquity 80:686-696

Gillmore GK, Coningham RA, Fazeli H, Young RL, Magshoudi M, Batt CM, Rushworth G (2009) Irrigation on the Tehran Plain, Iran: Tepe Pardis, The site of a possible Neolithic irrigation feature? Catena 78 (3):285-300

Grigson C (1995) Plough and Pasture in the Early Economy of the Southern Levant. In: Levy TE (ed) The Archaeology of Society in the Holy Land. Facts on File, New York, pp 245-280

Harrower M (2009) Is the hydraulic hypothesis dead yet? Irrigation and social change in ancient Yemen. World Archaeology 41 (1):58-72

Heaton THE (1999) Spatial, Species, and Temporal Variations in the ${ }^{13} \mathrm{C} /{ }^{12} \mathrm{C}$ Ratios of $\mathrm{C}_{3}$ Plants: Implications for Palaeodiet Studies. Journal of Archaeological Science 26:637-649

Heaton THE, Jones G, Halstead P, Tsipropoulos $\mathrm{T}$ (2009) Variations in the ${ }^{13} \mathrm{C} /{ }^{12} \mathrm{C}$ ratios of modern wheat grain, and implications for interpreting data from Bronze Age Assiros Toumba, Greece. Journal of Archaeological Science 36:2224-2233

Helbaek H (1960) Ecological effects of irrigation in ancient Mesopotamia. Iraq 22:186-196

Helms S (1989) Jawa at the beginning of the Middle Bronze Age. Levant 21:141-168 
Helms SW (1981) Jawa: Lost city of the Black Desert. Methuen, London

Hoefs J (1997) Stable Isotope Geochemistry. fourth edn. Springer Verlag, Heidelberg

Hubick KT, Hammer GL, Farquhar GD, Wade LJ, Caemmerer Sv, Henderson SA (1990) Carbon Isotope Discrimination Varies Genetically in C4 Species. Plant Physiology 91:534-537

Hunt RC (1994) Reply to Price. Journal of Anthropological Research 50:205-211

Jenkins E, Jamjoum K, Nuimat S (2011) Irrigation and phytolith formation: an experimental study. In: Mithen S, Black E (eds) Water, Life, and Civilisation: Climate, Environment and Society in the Jordan Valley. Cambridge University Press, Cambridge, pp 347-372

Jones G, Charles M, Bogaard A, Hodgson JG, Palmer C (2005) The functional ecology of present-day arable weed floras and its applicability for the identification of past crop husbandry. Vegetation History and Archaeobotany 14:493-504

Kaptijn E (2010) Communality and power: irrigation in the Zerqa Triangle, Jordan. Water History 2:145-163

Körner C, Farquhar GD, Roksandic Z (1988) A global survey of carbon isotope discrimination in plants from high altitude. Oecologia (Berlin) 74:623-632

Körner C, Farquhar GD, Wong SC (1991) Carbon isotope discrimination by plants follows latitudinal and altitudinal trends. Oecologia (Berlin) 88:30-40

Kuijt I, Finlayson B, MacKay J (2007) Pottery Neolithic landscape modification at Dhra'. Antiquity $81: 106-118$

Laundré JW (1999) Relationships between water availability, carbon isotope discrimination and plant productivity in two semi-arid grass and shrub species. Journal of Arid Environments 41:49-60

Levy TE (1995) Cult, Metallurgy and Rank Societies - Chalcolithic Period (ca. 4500-3500BCE). In: Levy TE (ed) The Archaeology of Society in the Holy Land. Facts on File, New York, pp $226-244$

Mabry J (1989) Investigations at Tell el-Handaquq, Jordan. ADAJ 33:59-95

Mabry J (1995) Early Town Development and Water Management in the Jordan Valley: Investigations at Tell el-Handaquq North. AASOR 53:115-154 
Madella M, Jones MK, Echlin P, Powers-Jones A, Moore M (2009) Plant water availability and analytical microscopy of phytoliths: Implications for ancient irrigation in arid zones. Quaternary International 193:32-40

Marino BD, DeNiro MJ (1987) Isotopic Analysis of Archaeobotanicals to Reconstruct Past Climates: Effects of Activities Associated with Food Preparation on Carbon, Hydrogen and Oxygen Isotope Ratios of Plant Cellulose. Journal of Archaeological Science 14:537-548

Matthews R (2009) People and complex societies of ancient Southwest Asia. In: Scarre C (ed) The human past. World Prehistory \& the Development of Human Societies. Thames \& Hudson, London, pp 432-471

McCreery DW (2003) The Paleoethnobotany of Bab edh-Dhra'. In: Rast WE, Schaub RT (eds) Bab edh-Dhra': Excavations at the Town Site (1975-1981). Part 1: Text. Eisenbrauns, Winona Lake, Indiana, pp 449-463

Migowski C, Stein M, Prasad S, Negendank JFW, Agnon A (2006) Holocene climate variability and cultural evolution in the Near East from the Dead Sea sedimentary record. Quaternary Research 66:421-431

Mithen S, Jenkins E, Jamjoum K, Nuimat S, Nortcliff S, Finlayson B (2008) Experimental crop growing in Jordan to develop methodology for the identification of ancient crop irrigation. World Archaeology 40 (1):7-25

Monneveux P, Rekika D, Acevedo E, Merah O (2006) Effect of drought on leaf gas exchange, carbon isotope discrimination, transpiration efficiency and productivity in field grown durum wheat genotypes. Plant Science 170:867-872

O'Leary MH (1981) Carbon Isotope Fractionation in Plants. Phytochemistry 20 (4):553-567

Oleson JP (2001) Water supply in Jordan through the ages. In: MacDonald B, Adams R, Bienkowski P (eds) The Archaeology of Jordan. Sheffield University Press, Sheffield, pp 603-624

Palumbo G (2008) The Early Bronze Age IV. In: Adams RB (ed) Jordan: An Archaeological Reader. Equinox Publishing, London, 
Peltenburg E, Colledge S, Croft P, Jackson A, McCartney C, Murray MA (2000) Agro-pastoralist colonization of Cyprus in the 10th millennium BP: initial assessments. Antiquity 74:844-853

Philip G (2008) The Early Bronze Age I-III. In: Adams RB (ed) Jordan: An Archaeological Reader. pp 161-226

Postgate JN (1994) Early Mesopotamia: Society and economy at the dawn of history. Routledge, London

Prag K (2007) Water Strategies in the Iktanu Region of Jordan. The History and Archaeology of Jordan IX:405-412

Price DH (1994) Wittfogel's neglected hydraulic/hydroagricultural distinction. Journal of Anthropological Research 50:187-204

Riehl S (2008) Climate and agriculture in the ancient Near East: a synthesis of the archaeobotanical and stable carbon isotope evidence. Vegetation History and Archaeobotany online

Riehl S, Bryson R, Pustovoytov K (2008a) Changing growing conditions for crops during the Near Eastern Bronze Age (3000-1200 BC): the stable carbon evidence. Journal of Archaeological Science 35:1011-1022

Riehl S, Pustovoytov KE, Hotchkiss S, Bryson RA (2008b) Local Holocene environmental indicators in Upper Mesopotamia: Pedogenic carbonate record vs. archaeobotanical data and archaeoclimatological models. Quaternary International. doi:10.1016/j.quaint.2008.06.012

Roberts N, Eastwood WJ, Kuzucuoğlu C, Fiorentino G, Caracuta V (2011) Climatic, vegetation and cultural change in the eastern Mediterranean during the mid-Holocene environmental transition. The Holocene 21 (1):147-162

Rollefson G (2008) The Neolithic Period. In: Adams RB (ed) Jordan: An Archaeological Reader. Equinox Publishing, London,

Rosen AM, Weiner S (1994) Identifying Ancient Irrigation: a New Method Using Opaline Phytoliths from Emmer Wheat. Journal of Archaeological Science 21:125-132

Salisbury FB, Ross CW (1992) Plant Physiology. Fourth edition. Fourth edn. Wadsworth Publishing Company, Belmont, California 
Scarborough VL (2003) The flow of power : ancient water systems and landscapes. SAR Press, Santa Fe, N.M.

Sealy J (2001) Body Tissue Chemistry and Palaeodiet. In: Brothwell DR, Pollard AM (eds) Handbook of Archaeological Sciences. John Wiley \& Sons, Chichester, pp 269-279

Shaheen R, Hood-Nowotny RC (2005) Effect of drought and salinity on carbon isotope discrimination in wheat cultivars. Plant Science 168:901-909

Staubwasser M, Weiss H (2006) Holocene climate and cultural evolution in late prehistoric-early historic West Asia. Quaternary Research 66:372-387

Stewart GR, Turnbull MH, Schmidt S, Erskine PD (1995) ${ }^{13} \mathrm{C}$ Natural Abundance in Plant Communities Along a Rainfall Gradient: a Biological Integrator of Water Availability. Australian Journal of Plant Physiology 22:51-55

Stokes HR (2008) Watering the Fields; testing the use of carbon stable isotopes for identifying ancient arid irrigation practices. Unpiblished MSc thesis, University of Reading.

Stokes HR, Müldner G, Jenkins E (2011) An investigation into the archaeological application of carbon stable isotope analysis used to establish crop water availability: solutions and ways forward. In: Mithen S, Black E (eds) Water, Life, and Civilisation: Climate, Environment and Society in the Jordan Valley. Cambridge University Press, Cambridge, pp 373-380

Tieszen LT (1991) Natural Variations in the Carbon Isotope Values of Plants: Implications for Archaeology, Ecology, and Paleoecology. Journal of Archaeological Science 18:227-248

Weiss H, Courty M-A, Wetterstrom W, Guichard F, Senior L, Meadow R, Curnow A (1993) The Genesis and Collapse of Third Millennium North Mesopotamian Civilization. Science 261:995-1004

Wenke RS (1990) Patterns in Prehistory: humankind's first three million years. 3rd edn. Oxford University Press, Oxford

Whitehead PG, Smith SJ, Wade AJ, Mithen SJ, Finlayson BL, Sellwood B, Valdes PJ (2008) Modelling of hydrology and potential population levels at Bronze Age Jawa, Northern Jordan: 
a Monte Carlo approach to cope with uncertainty. Journal of Archaeological Science 35 (3):517-529

Wright P (2003) Preservation or destruction of plant remains by carbonization? Journal of Archaeological Science 30:577-583

Figure captions

Fig. 1 Map showing the location of the crop growing sites

Fig. 2 Schematic representation of the lay-out of the crop growing experiments, based on the lay-out of Khirbet as-Samra, but similar for all stations (after data from Khalil Jamjoum and personal observation). In the first growing season no $40 \%$ regime was present, but this was added for the second and third season of growing wheat and barley and was present in both growing seasons of sorghum

Fig. 3 Relationship between irrigation regime and $\Delta^{13} \mathrm{C}$ values of barley grains $\left(\mathrm{r}^{2}\right.$ is 0.53$)$. Average $\Delta^{13} \mathrm{C}$ values with standard deviation $(1 \sigma)$ for all three sites together are given

Fig. 4 Relationship between total water input (rainfall and applied irrigation in $\mathrm{mm}$ for the total growing season) and $\Delta^{13} \mathrm{C}$ values of barley grains for all three sites. Average values of three samples of ten grains per plot per year are used (standard deviation $1 \sigma$ ). The plotted graph is a logarithmic function with an $\mathrm{r}^{2}$ of 0.53 . When the outlier with a low $\Delta^{13} \mathrm{C}$ of $15.41 \%$ at around $300 \mathrm{~mm}$ of water input (representing the $0 \%$ plot at Deir 'Alla in 2005-2006) is taken out, the $r^{2}$ improves to 0.63 . The relationship would be further strengthened when the outlier would be removed from the plot which received about $100 \mathrm{~mm}$ of water, but which has an unexpectedly high $\Delta^{13} \mathrm{C}$ of over $17 \%$ (representing the Deir 'Alla 0\% plot in 2007-2008; $\mathrm{r}^{2}$ would then be 0.68) 
Fig. 5 Relationship between water input during grain filling and $\Delta^{13} \mathrm{C}$ values of barley grains for all three sites, compared to earlier published data concerning barley grown in Spain (Araus et al. 1997b). The grain filling period was taken to be the 'harvest stage', as observed in the field and according to FAO guidelines (Doorenbos and Pruitt 1977). In addition, the relationship between $\Delta^{13} \mathrm{C}$ values of barley grains and water input during 40 days before irrigation was stopped is shown. Error bars are left out for sake of clarity; standard deviation $(1 \sigma)$ varies between 0.02 and 0.65 , with an average of 0.22

Fig. 6 Relationship between irrigation regime and $\Delta^{13} \mathrm{C}$ values of barley grains per site. For sake of clarity averages are given representing three years and three samples per irrigation regime for every year (standard deviation $1 \sigma$ ). Black lozenges indicate Deir 'Alla, grey boxes Ramtha, and open triangles Khirbet as-Samra

Fig. 7 Relationship between water input (rainfall and applied irrigation in $\mathrm{mm}$ for the total growing season) and $\Delta^{13} \mathrm{C}$ values of barley grains per site. Standard deviations are as in figure 4 , but not shown here. Lozenges indicate Deir 'Alla, boxes Ramtha and open triangles Khirbet as-Samra

Fig. 8 Relationship between irrigation regime and $\Delta{ }^{13} \mathrm{C}$ of sorghum grains for the 2009 growing season. Averages per plot are shown. Black lozenges indicate Deir 'Alla, grey boxes Ramtha, and open circles farm of Sameeh Nuimat

Table captions

Table 1 Location and environmental characteristics of the three crop growing stations (Carr 2009, Jenkins et al. 2011, Stokes et al. 2011). Rainfall, temperature and relative humidity (RH\%) data from Khalil Jamjoum and the National Centre for Agricultural Research and Extension, as measured on the crop growing stations and calculated for the growing seasons (planting in November/December harvest in May)

*temperature data from 21/12/2007 - 31/12/2007 are missing for Khirbet as-Samra 
**RH\% data from 21/12/2007 - 31/12/2007 and from 21/01/2008 - 31/01/2008 are missing for Khirbet as-Samra 